\title{
Outcomes of Clostridium difficile-suspected diarrhea in a French university hospital
}

\author{
Nagham Khanafer ${ }^{1,2}$. Philippe Vanhems ${ }^{1,2}$ • Frédéric Barbut ${ }^{3,4}$. Catherine Eckert ${ }^{3,4}$ - Michel Perraud ${ }^{1}$. \\ François Vandenesch ${ }^{5} \cdot$ Christine Luxemburger $^{6} \cdot$ Clarisse Demont $^{6} \cdot$ CDIO1 Study Group
}

\begin{abstract}
Clostridium difficile infection (CDI) produces a variety of clinical presentations ranging from mild diarrhea to severe infection with fulminant colitis, septic shock, and death. CDI puts a heavy burden on healthcare systems due to increased morbidity and mortality, and higher costs. We evaluated the clinical impact of CDI in terms of complications and mortality in a French university hospital compared with patients with diarrhea unrelated to CDI. A 3-year prospective, observational, cohort study was conducted in a French university hospital. Inpatients aged 18 years or older with CDI-suspected diarrhea were eligible to participate in the study and were followed for up to 60 days after CDI testing. Among the 945 patients with diarrhea included, 233 had confirmed CDI. Overall, 106 patients (11.2\%) developed at least one of the following complications: colectomy, colitis, ileitis/rectitis, ileus, intestinal perforation, megacolon, multiorgan failure, pancolitis, peritonitis, pseudomembranous colitis, renal failure, and sepsis/ septic shock. The complication rate was significantly higher in patients with diarrhea related to $C$. difficile than in non-CDI patients $(26.6 \%$ vs $6.2 \%, P<0.001)$. At day 60, 137 (14.5\%) patients had died, with 37 deaths among the CDI group (15.9\%). Death was attributable to CDI in 15 patients (6.4\%). Complications are more frequent among CDI cases than in patients with diarrhea not related to $C$. difficile. Assessment of CDI is necessary to ensure allocation of sufficient resources to CDI prevention.
\end{abstract}

Keywords Clostridium difficile infection · Complication · Prognosis · Recurrence · Ribotype

Nagham Khanafer

naghamkhanafer@hotmail.com; nagham.khanafer@chu-lyon.fr

1 Service d'Hygiène, Épidémiologie Infectiovigilance et Prévention, Groupement Hospitalier Centre, Hôpital Edouard Herriot, Hospices Civils de Lyon, Place d'Arsonval, 69437 Lyon Cedex 03, France

2 Laboratoire des Pathogènes Emergents - Fondation Mérieux, Centre International de Recherche en Infectiologie, Institut national de la santé et de la recherche médicale U1111, Centre National de la Recherche Scientifique UMR5308, Ecole Normale Supérieure de Lyon, Université Claude Bernard 1, Lyon, France

3 Laboratoire C. difficile associé au CNR des bactéries anaérobies, Hôpital Saint-Antoine, Assistance Publique-Hôpitaux de Paris, Paris 12, France

4 GRC no. 2 EPIDIFF, Université Pierre et Marie Curie, Paris, France

5 Hospices Civils de Lyon, Institut des Agents Infectieux, Lyon, France

6 Sanofi Pasteur, Lyon, France

\section{Introduction}

Clostridium difficile is the most common cause of nosocomial diarrhea and a major financial burden for healthcare systems $[1,2]$. The epidemiology of Clostridium difficile infection (CDI) has changed since the emergence of the 027/NAP1/BI epidemic strain, implicated in large outbreaks and major increases in the incidence and severity of the disease [3, 4]. The clinical presentation of CDI ranges from mild to severe diarrhea, pseudomembranous colitis (PMC), toxic megacolon, intestinal perforation, sepsis, and ultimately death [5]. The pathophysiology for this variation remains poorly understood and mortality rates also vary widely $(0.6$ to $83 \%)$ [6]. The epidemiology of CDI in France is only partially described in a limited number of papers $[7,8]$. Consequently, we undertook a prospective cohort study of CDI in a French university hospital to describe the prognosis of patients suffering from $C$. difficile-associated diarrhea. Rates of complications, including mortality, were compared between patients with CDIassociated diarrhea and those with diarrhea unrelated to 
CDI. Polymerase chain reaction (PCR) ribotype was also assessed.

\section{Methods}

\section{Study location and patients}

Between February 22, 2011 and February 28, 2014, a prospective observational cohort study was conducted in Edouard Herriot Hospital, Hospices Civils de Lyon, a public teaching hospital in Lyon, France ( 832 beds). Patients aged 18 years or older, hospitalized, and suspected to have CDI were eligible to participate. Outpatients, day-care patients, and patients who refused to participate or were unable to sign the consent form were excluded. Eligible patients who agreed to participate and signed a consent form were included and followed for up to 2 months after CDI testing. The study protocol was approved by the hospital institutional review board (Comité de Protection des Personnes et Comité National Informatique et Liberté) and ethics committee.

\section{Data collection}

Patients were actively followed during hospitalization to collect data related to evolution of the diarrheal episode, the occurrence of complications, and death. Data were collected from the clinician in charge of the patient (by phone call), the computerized medical record, the nursing record, and an interview with the patient or a family member during hospital stay or after discharge. For each patient, we completed a standardized form that included information on the following: age, gender, co-morbidities, data on hospital stay, symptoms (e.g., diarrhea, number of stools, fever, abdominal pain, and nausea and vomiting), results of biological and microbiological tests, and infection outcome. After discharge, data were obtained by calling patients and/or their referent physician at days 30 (D30) and 60 (D60).

\section{Microbiological data}

C. difficile testing was performed on liquid stool samples after specific request from the physician. Before November 2011, the presence of $C$. difficile was assessed by enzyme immunoassay (EIA, ImmunoCard $\AA$ Toxins A\&B, Meridian Biosciences) of fresh stool samples and by culture on selective media (algorithm 1; Alg1). If the EIA yielded negative toxin results but the culture was positive for $C$. difficile, the toxicity of the isolate was assessed in vitro by toxigenic culture. Between November 2011 and January 2013, a glutamate dehydrogenase $(\mathrm{GDH})$ antigen screening test (ImmunoCard ${ }^{\circledR} C$. difficile GDH assay, Meridian Biosciences) was used first. If positive, stools were subsequently tested for $C$. difficile toxins
$\mathrm{A}$ and $\mathrm{B}$ by EIA and culture as for Alg1 (Alg2). From February 2013, the laboratory replaced the Alg2 method with a combined immunochromatographic test for GDH and toxins (C. DIFF QUIK CHEK COMPLETE®, Alere) coupled with polymerase chain reaction (PCR, GeneXpert ${ }^{\circ}$ Systems, Cepheid). If the screening test was positive and the toxin tests were negative, PCR was performed as a confirmatory test (Alg3).

Characterization of isolates was performed using an inhouse multiplex PCR assay that detected $t p i, t c d A, t c d B$, $t c d C, c d t A$, and $c d t B$ genes coding for triose phosphate isomerase, toxin $\mathrm{A}$, toxin $\mathrm{B}, \mathrm{TcdC}$, and the two components of the binary toxin, respectively. The PCR ribotype was assessed by capillary gel electrophoresis. Primer sequences were described by Bidet et al. [9], labeled at the $5^{\prime}$ end with fluorochrome. Banding patterns were analyzed with GeneMapper software (Applied Biosystems) and compared to 26 reference strains from the European collection (Pr. Ed Kuijper, Leiden University) [7].

\section{Definitions}

Diarrhea was defined as three or more unformed stools per 24$h$ period. A CDI case was a patient with diarrhea and a positive stool test result (EIA for toxins A and/or B or positive toxigenic culture or immunochromatographic test or PCR) and/or endoscopically or histologically proven colitis due to $C$. difficile. Recurrence was defined if symptoms reappeared at least 10 days after, but no more than 2 months after, the resolution of the first episode, and was accompanied by a $C$. difficile-positive test result. All other cases of diarrhea were assumed non-CDI cases.

\section{Outcomes examined}

Outcomes of interest included the crude and attributable 30and 60-day mortality rates and rates of complications. For each death, clinicians in charge of patients judged independently whether CDI was a primary cause, a contributory cause, or unrelated to the cause of death.

\section{Statistical analysis}

Outcomes in CDI-confirmed patients and those with diarrhea not related to $C$. difficile were described as follows: good (resolution of diarrhea) without complications, with complications, recurrences, in-hospital death, and death at D30 and D60. Rates of complications between CDI and non-CDI patients were also compared using chi-square or Fisher's exact test for qualitative variables in SPSS (version 17.0 for Windows, SPSS, Inc., Chicago, IL). A two-tailed $P$ value $<$ 0.05 was considered statistically significant in all tests. 


\section{Results}

Between February 2011 and February 2014, 945 patients fulfilled the inclusion criteria and were included in the study: 233 with CDI and 712 with non-CDI diarrhea, which represented a CDI incidence of 2.15 per 1000 hospitalized patients or 3.11 per 10,000 hospital-days. The characteristics of study population are given in Table 1. There were more males than females: $52.5 \%$ vs $47.5 \%$. The mean of length of stay at hospital was 31.1 days (min-max 2-414) with a median of 18 days (IQR 9-40.5). Forty percent of cases were diagnosed in the intensive care unit (ICU) or emergency room (patients hospitalized $\geq 48 \mathrm{~h}$ in the emergency department).

\section{Complications}

Diarrheal episodes resolved without complication in 769 $(81.4 \%)$ patients, and 87 (9.2\%) died before resolution of their symptoms. The evolution of initial diarrheal episodes is described in Table 2. Overall, $105(11.1 \%)$ patients developed at least one of the following complications (Table 3): colectomy, colitis, ileitis/rectitis, ileus, intestinal perforation, megacolon, multiorgan failure, pancolitis, peritonitis, PMC, renal failure, and sepsis/septic shock. Pancolitis, colitis, and acute renal failure were the most common complications. Complications occurred in $26.6 \%$ $(n=62)$ of patients with CDI and $6.0 \%(n=43)$ with nonCDI diarrhea $(P<0.001)$. Among the 62 patients with complicated CDI, 45 (19.3\%) developed one complication and $17(7.3 \%)$ experienced at least two complications. The most frequent complications in the CDI group were colitis and/or pancolitis $(n=33,14.2 \%)$, acute renal failure $(n=24,10.3 \%)$, sepsis/septic shock $(n=9,3.9 \%)$, ileitis/rectitis $(n=5,2.2 \%)$, and colectomy $(n=5,2.2 \%)$. Pseudomembranous colitis (PMC) was observed alone in three $(1.3 \%)$ patients with CDI or associated with other complications in another four (1.7\%) patients. Acute renal failure was diagnosed in $15(88.2 \%)$ patients with more than one complication.

At D30, two patients had been admitted to ICU for CDI, six presented with renal failure, and two had colitis or septic shock. By D60, CDI was diagnosed in one patient with initial diarrhea not related to $C$. difficile and two patients were readmitted for diarrhea.

\section{Mortality and recurrences}

Overall, 848 and 808 patients were alive at D30 and D60, respectively, after the laboratory testing for CDI. At D60, the cumulative rate of recurrence was $13.7 \%(n=32) ; 22$ (9.4\%) had recurrence of diarrhea by D30 and $10(4.3 \%)$ from D30 to D60. By the end of follow-up, 137 (14.5\%) patients had died. Among those with CDI, 25 (10.7\%)
Table 1 Characteristics of patients included between February 2011 and February 2014

\begin{tabular}{|c|c|}
\hline Variables & $N=945$ patients $(\%)$ \\
\hline Median age (IQR) (years) & $68.1(52.5-79.9)$ \\
\hline Gender ratio (male:female) & 1.1 \\
\hline \multicolumn{2}{|c|}{ Exposure to risk factors for CDI before onset of diarrhea } \\
\hline \multicolumn{2}{|l|}{ In the last 60 days } \\
\hline Antibiotics & $595(63.0)$ \\
\hline \multicolumn{2}{|l|}{ In the last 30 days } \\
\hline Antivirals & $114(12.1)$ \\
\hline Immuno-suppressors & $353(37.4)$ \\
\hline Medical procedures & $346(36.6)$ \\
\hline Gastro-intestinal surgery & $136(14.4)$ \\
\hline Nasogastric intubation & $201(21.3)$ \\
\hline Stoma & $41(4.3)$ \\
\hline Other & $104(11.0)$ \\
\hline Recent hospitalization ${ }^{1}$ & $315(33.3)$ \\
\hline Residency in nursing home & $43(4.6)$ \\
\hline \multicolumn{2}{|l|}{ Current use since at least 30 days } \\
\hline Treatment with anti-acids & $653(69.1)$ \\
\hline PPI & $615(65.1)$ \\
\hline Anti $\mathrm{H} 2$ & $58(6.1)$ \\
\hline \multicolumn{2}{|l|}{ In the last 3 days } \\
\hline Anti-diarrheal medication & $40(4.2)$ \\
\hline Colic preparation & $43(4.6)$ \\
\hline Laxatives & $290(30.7)$ \\
\hline \multicolumn{2}{|l|}{ Underlying diseases } \\
\hline Cardiovascular disease & $562(59.5)$ \\
\hline Diabetes mellitus & $261(27.6)$ \\
\hline Gastro-intestinal disease & $171(18.1)$ \\
\hline Hepatic disease & $111(11.7)$ \\
\hline Malignancy & $250(26.5)$ \\
\hline $\begin{array}{l}\text { Malnutrition (when patient was referred } \\
\text { to dietitian) }\end{array}$ & $333(35.2)$ \\
\hline Nervous system disease & $177(18.7)$ \\
\hline Pulmonary disease & $204(21.6)$ \\
\hline Renal disease & $260(27.5)$ \\
\hline Systemic disease & $50(5.3)$ \\
\hline Vascular peripheral disease & $141(14.9)$ \\
\hline Other & $275(29.1)$ \\
\hline
\end{tabular}

${ }^{1}$ Before the first episode of diarrhea suspected to be related to $C$. difficile. $C D I C$. difficile infection, Anti $\mathrm{H} 2$ histamine $\mathrm{H} 2$ receptor blocker, $P P I$ proton pump inhibitor. Variables were described by number and percentage $(n(\%))$ except age described by median and interquartile (IQR)

died by D30 which increased to 37 (15.9\%) total deaths within 60 days of diagnosis. Death was related to CDI in 15 patients (principal cause in 2 patients and contributing cause in 13 patients), which represented $40.5 \%$ (15/37) of deaths in those with CDI. 
Table 2 Global evolution of diarrheal episodes in patients with CDI and in patients with diarrhea not related to C. difficile

\begin{tabular}{|c|c|c|c|}
\hline Evolution of diarrheal episode & $\begin{array}{l}\text { Study population, } \\
N=945(\%)\end{array}$ & $\begin{array}{l}\text { Patients with confirmed } \\
\text { CDI, } N=233(\%)\end{array}$ & $\begin{array}{l}\text { Patients with diarrhea not related } \\
\text { to } C \text {. difficile, } N=712(\%)\end{array}$ \\
\hline Good, (cessation of diarrhea) without complications & $769(81.4)$ & $155(66.5)$ & $614(86.2)$ \\
\hline Complications, then good & $84(8.9)$ & $47(20.2)$ & $37(5.2)$ \\
\hline Good, (cessation of diarrhea) then death within 2 weeks & $39(4.1)$ & $8(3.4)$ & $31(4.4)$ \\
\hline Death $^{1}$ & $35(3.7)$ & $10(4.3)$ & $25(3.5)$ \\
\hline Complications, then death & $13(1.4)$ & $8(3.4)$ & $5(0.7)$ \\
\hline Admission to ICU for CDI & $5(0.5)$ & $5(5.1)$ & $0(0)$ \\
\hline
\end{tabular}

${ }^{1}$ Diarrhea was present at date of death. CDI C. difficile infection. ICU intensive care unit. Variables were described by number and percentage $(n(\%))$

\section{Strains characterization}

One hundred and twenty-three isolate $(52.8 \%)$ from patients with CDI were available for typing. Eighteen PCR ribotypes were identified and 19 (15.4\%) isolates had PCR ribotypes different from the 26 ribotypes used for comparison (Table 4). The six main PCR ribotypes were 014/020/077 (23.6\%; 29 isolates), 002 (12.2\%; 15 isolates), $078 / 126$ (8.9\%; 11 isolates), 015 (6.5\%; 8 isolates), 005 (4.9\%; 6 isolates), and 001 (4.1\%; 5 isolates), which accounted for $60.2 \%$ (74 isolates) of typed strains. Only one historical 027 strain (susceptible to erythromycin and moxifloxacin) was identified.
Table 3 Complications observed during the first episode of diarrhea

\begin{tabular}{|c|c|c|c|c|}
\hline Number & $\begin{array}{l}\text { Complications }{ }^{1} \text { observed in patients during the first } \\
\text { episode }\end{array}$ & $\begin{array}{l}\mathrm{CDI}, \\
N=233(\%)\end{array}$ & $\begin{array}{l}\text { Not CDI, } \\
N=712(\%)\end{array}$ & $P$ \\
\hline \multirow[t]{8}{*}{1} & Colectomy & $0(0)$ & $2(0.3)$ & 1 \\
\hline & Colitis & $14(6.0)$ & $8(1.1)$ & $<10^{-3}$ \\
\hline & Ileitis/rectitis & $4(1.7)$ & $3(0.4)$ & 0.12 \\
\hline & Ileus & $0(0)$ & $1(0.1)$ & 1 \\
\hline & Pancolitis & $13(5.6)$ & $3(0.4)$ & $<10^{-3}$ \\
\hline & $\mathrm{PMC}$ & $3(1.9)$ & $0(0)$ & 0.02 \\
\hline & Renal failure & $9(3.9)$ & $20(2.8)$ & 0.56 \\
\hline & Sepsis/septic choc & $2(0.9)$ & $1(0.1)$ & 0.56 \\
\hline \multirow[t]{10}{*}{2} & Colitis + colectomy & $1(0.4)$ & $0(0)$ & 0.56 \\
\hline & Colitis + septic shock & $0(0)$ & $1(0.1)$ & 1 \\
\hline & Ileitis + pancolitis & $0(0)$ & $2(0.3)$ & 1 \\
\hline & Ileitis + PMC & $1(0.4)$ & $0(0)$ & 0.56 \\
\hline & Ileitis + renal failure & $0(0)$ & $1(0.1)$ & 1 \\
\hline & Organ failure + renal failure & $1(0.4)$ & $1(0.1)$ & 1 \\
\hline & Pancolitis + renal failure & $2(0.9)$ & $0(0)$ & 0.10 \\
\hline & $\mathrm{PMC}+$ renal failure & $2(0.9)$ & $0(0)$ & 0.10 \\
\hline & Peritonitis + renal failure & $1(0.4)$ & $0(0)$ & 0.56 \\
\hline & Septic shock + renal failure & $2(0.9)$ & $0(0)$ & 0.10 \\
\hline \multirow[t]{3}{*}{3} & Renal failure + colectomy + septic shock & $1(0.4)$ & $0(0)$ & 0.56 \\
\hline & Renal failure + colitis + ileus & $1(0.4)$ & $0(0)$ & 0.56 \\
\hline & Renal failure + pancolitis + septic shock & $1(0.4)$ & $0(0)$ & 0.56 \\
\hline \multirow[t]{2}{*}{4} & Colitis + septic shock + pancolitis + renal failure & $1(0.4)$ & $0(0)$ & 0.56 \\
\hline & $\begin{array}{l}\text { Renal failure + peritonitis }+ \text { colectomy }+ \text { intestinal } \\
\text { perforation }\end{array}$ & $1(0.4)$ & $0(0)$ & 0.56 \\
\hline 5 & $\begin{array}{l}\text { Organ failure }+ \text { septic shock }+ \text { renal failure }+ \\
\text { megacolon }+ \text { colectomy }\end{array}$ & $1(0.4)$ & $0(0)$ & 0.56 \\
\hline 6 & $\begin{array}{l}\text { Organ failure + septic shock + renal failure + PMC } \\
+ \text { ileus + colectomy }\end{array}$ & $1(0.4)$ & $0(0)$ & 0.56 \\
\hline
\end{tabular}

${ }^{1}$ Complications not including death. CDI C. difficile infection, $P M C$ pseudomembranous colitis. Variables were described by number and percentage $(n(\%))$ 
Table 4 Ribotypes in patients with CDI

\begin{tabular}{|c|c|c|c|c|c|c|}
\hline \multirow[t]{2}{*}{ PCR ribotypes } & \multirow{2}{*}{$\begin{array}{l}\text { Typed strains } \\
N(\%)\end{array}$} & \multicolumn{2}{|c|}{$\begin{array}{l}\text { Development of } \\
\text { complications during the } \\
\text { first episode of CDI }\end{array}$} & \multirow[t]{2}{*}{$\begin{array}{l}\text { Complications }{ }^{1} \text { observed in CDI patients } \\
\text { with typed strains (number) }\end{array}$} & \multirow{2}{*}{$\begin{array}{l}\text { Death by the end } \\
\text { of follow-up } \\
N(\%), n=23\end{array}$} & \multirow{2}{*}{$\begin{array}{l}\text { Death related to CDI } \\
\text { (among typed strains) } \\
N(\%)\end{array}$} \\
\hline & & Non, $n=95$ & Yes, $n=29$ & & & \\
\hline 001 & $5(4)$ & $3(3.2)$ & $2(6.9)$ & Colitis (1); pancolitis (1) & $0(0)$ & $0(0)$ \\
\hline 002 & $15(12.1)$ & $12(12.6)$ & $3(10.3)$ & Colitis (2); PMC + renal failure (1) & $7(30.4)$ & $1(14.3)$ \\
\hline 003 & $4(3.2)$ & $3(3.2)$ & $1(3.4)$ & Ileitis/rectitis (1) & $1(4.3)$ & $1(100)$ \\
\hline 005 & $6(4.8)$ & $5(5.3)$ & $1(3.4)$ & $\mathrm{PMC}+$ renal failure $(1)$ & $1(4.3)$ & $0(0)$ \\
\hline 012 & $3(2.4)$ & $2(2.1)$ & $1(3.4)$ & Colitis (1) & $0(0)$ & $0(0)$ \\
\hline 014/020/077 & $29(23.4)$ & $27(28.4)$ & $2(6.9)$ & $\begin{array}{l}\text { Renal failure + colitis + ileus (1); renal } \\
\text { failure + peritonitis + colectomy + } \\
\text { intestinal perforation }(1)\end{array}$ & $5(21.7)$ & $2(40)$ \\
\hline 015 & $8(6.5)$ & $5(5.3)$ & $3(10.3)$ & Renal failure (1) & $0(0)$ & $0(0)$ \\
\hline 019 & $2(1.6)$ & $0(0)$ & $2(6.9)$ & Colitis (1) & $0(0)$ & $0(0)$ \\
\hline 023 & $2(1.6)$ & $1(1.1)$ & $1(3.4)$ & Renal failure (1) & $1(4.3)$ & $1(100)$ \\
\hline 027 & $1(0.8)$ & $0(0)$ & $1(3.4)$ & Sepsis (1) & $1(4.3)$ & $1(100)$ \\
\hline 029 & $2(1.6)$ & $2(2.1)$ & $0(0)$ & & $0(0)$ & $0(0)$ \\
\hline 046 & $1(0.8)$ & $1(1.1)$ & $0(0)$ & & $0(0)$ & $0(0)$ \\
\hline 050 & $3(2.4)$ & $3(3.2)$ & $0(0)$ & & $0(0)$ & $0(0)$ \\
\hline 056 & $1(0.8)$ & $1(1.1)$ & $0(0)$ & & $0(0)$ & $0(0)$ \\
\hline $078 / 126$ & $11(8.9)$ & $8(8.4)$ & $3(10.3)$ & Pancolitis (2); renal failure (1) & $0(0)$ & $0(0)$ \\
\hline 081 & $3(2.4)$ & $2(2.1)$ & $1(3.4)$ & Colitis (1) & $0(0)$ & $0(0)$ \\
\hline 087 & $4(3.2)$ & $2(2.1)$ & $2(6.9)$ & $\begin{array}{l}\text { Pancolitis + renal failure (1); colitis + septic } \\
\text { shock + pancolitis + renal failure }(1)\end{array}$ & $1(4.3)$ & $1(100)$ \\
\hline 106 & $4(3.2)$ & $3(3.2)$ & $2(6.9)$ & $\begin{array}{l}\text { Pancolitis (1); Organ failure + septic shock + } \\
\text { renal failure + megacolon+ colectomy }(1)\end{array}$ & $1(4.3)$ & $1(100)$ \\
\hline Others & $19(15.3)$ & $15(15.8)$ & $4(13.8)$ & $\begin{array}{l}\text { Colitis (1); pancolitis (1); organ failure + renal } \\
\text { failure (1) }\end{array}$ & $5(21.7)$ & $1(20)$ \\
\hline
\end{tabular}

${ }^{1}$ Complications not including death; CDI C. difficile infection; $P M C$ pseudomembranous colitis. Variables were described by number and percentage $(n$ $(\%))$

Strains in two patients who developed recurrence were characterized as 078/126 and were similar in initial and recurrent episodes.

Twenty-three strains $(62.2 \% ; 23 / 37)$ were typed in patients with CDI who died and more than half of the isolates were of ribotypes 002 (30.4\%) and 014/020/077 (21.7\%). Among the deaths where CDI was listed as causative, five patients were infected with strains 003, 023, 027, 087, or 106.

\section{Discussion}

Over the past decade, the epidemiology of CDI has changed worldwide [3, 10-15]. The incidence of CDI in our hospitalized cohort was lower than in other studies, but comparable to a recent national study [7]. In 2013, the incidence increased as a consequence of increased sensitivity [16]. However, molecular technics do not distinguish asymptomatic colonization from CDI; therefore, in our hospital, testing was limited to symptomatic patients.
In our prospective cohort study, the rate of complications was significantly higher in patients with confirmed CDI. Overall, 26.6\% of patients with CDI experienced one or more complications, which is higher than the rate of 8 to $12.2 \%$ previously reported, even though definition of complicated CDI and duration of follow-up were not the same [17-20]. Most studies of patients with CDI have focused mainly on outcomes such as mortality, length of stay, recurrence, and cost $[21,22]$. Although these are important, additional data on complications should be examined to evaluate the real burden of CDI.

Admissions to the ICU for CDI-associated complications and treatments for complicated disease such as colectomy are expected to rise [21]. The overall rate of colectomy in our study was $2.1 \%(5 / 233)$, slightly higher than report elsewhere (0.88-1.4\%) [23-25]. Colectomy with megacolon, PMC, and ICU admission is frequently reported in the literature and commonly used to define the clinical presentation of CDI as severe/complicated or not severe/not complicated. This classification is important as it helps guide clinicians in the 
management of infected patients, but not satisfactory for understanding the true impact of CDI. Many complications described in our study have not been adequately reported in terms of their frequency of occurrence in CDI, notably renal failure. Even the rate of CDI complications outside the large intestine remains to be fully determined.

Recurrence of diarrhea is particularly troublesome with CDI; there is $20-30 \%$ recurrence after an initial episode [21]. Such recurrent CDI diarrhea is often associated with prolonged hospital stays, excessive costs related to hospital readmission, and additional antibiotic therapy. The recurrence rate in our study $(13.7 \%$; 32/233) fits well with worldwide data (3.3 to $47.2 \%$ ) despite the often different clinical definitions used in those earlier studies and used an arbitrary period (from first episode to recurrence), varying from 6 weeks to 1 year [20,22, 26, 27]. A standardized duration of follow-up is required to define recurrence and ensure greater comparability between studies. Patients included in our study were followed actively for up to 60 days after diagnosis. We found that CDI recurrences in two cases were due to relapse with an antecedent strain of $C$. difficile which is consistent with other data [28].

Several studies have reported an increase in mortality since 2000 [29-31]. In our prospective study, CDI was considered to be the primary or a contributory cause in $15(6.4 \%)$ deaths (up to D60), which appears a higher rate than reported for elsewhere in France (mortality at D30: $4 \%$ and at D60: $3.4 \%)$ and the Netherlands (3.3\% at D30) [7, 25, 32]. However, this rate is similar to that reported elsewhere [33, 34]. In Europe, 30-day mortality varied between $6.8 \%$ in Ireland to $42 \%$ in the UK. The weighted average 30-day mortality ranged from 3\% in France to $30 \%$ in the UK [22]. Heterogeneity among published studies in terms of definitions, patient groups, type and quality of study, duration of follow-up, and information collected does not allow the comparison of mortality rates in CDI patients [35].

The most common $C$. difficile ribotype identified in our study was similar to those reported recently in France [7]. The main PCR ribotypes identified in a recent multicentric European study were 027, 001/072, and 014/020 [36]. The distribution of PCR ribotypes may vary from one country to another and even from one region to another [7, 36]. PCR ribotype 027, although predominant in Europe, was identified in only one $(0.8 \%)$ of the isolates typed in our study (the patient died with CDI listed as causative). Active surveillance with rapid action for new cases was ongoing during the study period, and no outbreaks were detected.

More than the half of the deaths in patients with CDI had ribotypes 002 and 014/020/077. Although no deaths in our study were attributed to these ribotypes, multiple studies have suggested that CDI may be more severe with certain ribotypes $[37,38]$. However, a growing body of data does not provide support for the "hypervirulent" hypothesis, although the clinical definition of outcomes or the methods used for data analysis were not consistent across all studies [39]. Indeed, the five deaths where CDI was attributed as causative in our study were with five different ribotypes. Overall, our findings indicate the little correlation between ribotype and severity of CDI.

The main strength of this study was that it was a prospective cohort study in which patients were actively followed for 2 months after CDI testing with no loss to follow-up. However, the study has some limitations. First, it was an observational study performed in a single university hospital. As such, caution is required in extrapolating our results to other healthcare facilities with different populations and approaches to managing CDI. Second, complications were recorded only when information was provided in patients' medical records. As such, there is a possibility that some complications may be underestimated. Third, data concerning strain genotype characteristics was not available for all included patients, and it is also possible that the clonal diversity of $C$. difficile isolates was underestimated.

In summary, patients with CDI appear to have frequently more complications than those with diarrhea not related to $C$. difficile. To our knowledge, this is the first study that quantifies the unfavorable outcomes of CDI, providing practitioners with a good summary of the clinical profile of the burden in France. Vaccination would be an attractive preventative strategy in the management of symptomatic CDI in clinical practice.

Acknowledgements Manuscript editing services were provided by Philip Jones and Richard Glover of inScience Communications, Springer Healthcare, funded by Sanofi Pasteur.

Monique Hulin and Luc Oltra (Epidemiology and Infection Control Unit, Edouard Herriot Hospital, Hospices Civils de Lyon, Lyon, France).

Dr. Olivier Dauwalder (Institut des Agents Infectieux, Hospices Civils de Lyon, Lyon, France).

Pr. Mustapha Adham, Pr. Laurent Argaud, Pr. Lionel Badet, Pr. Xavier Barth, Dr. Malik Bertrand, Pr. Carole Burillon, Pr. Roland Chapurlat, Dr. Michel Chuzeville, Pr. François Disant, Pr. Arnaud Hot, Pr. Laurent Juillard, Pr. Patrick Lermusiaux, Dr. Catherine Bohas Lombard, Dr. Geraldine Martin-Gaujard, Pr. Olivier Monneuse, Pr. Emmanuel Morelon, Pr. Thierry Ponchon, Pr. Emmanuel Poulet, Pr. Thomas Rimmelé, Pr. Karim Tazarourte, and their teams (Edouard Herriot Hospital, Hospices Civils de Lyon, Lyon).

Funding This study was funded by Sanofi Pasteur, Lyon, France.

\section{Compliance with ethical standards}

Conflict of interest Nagham Khanafer received a PhD grant from Sanofi Pasteur, non-financial support (travel expenses) from Alere, Astellas, and Sanofi Pasteur, and personal fees from Astellas; Frédéric Barbut received personal fees and non-financial support (travel expenses) from Astellas Pharma Europe, Sanofi Pasteur, Pfizer, and Merck and scientific grants from Astellas Pharma Europe, bioMérieux, bioSynex, Cepheid, Cubist, Diasorin, Quidel-Buhlmann, and R-bioPharm; Philippe Vanhems received scientific grants from Sanofi Pasteur, Sanofi MSD, and Anios 
and personal fees from Sanofi Pasteur, BioMérieux, GSK, and Sanofi MSD; Christine Luxemburger and Clarisse Demont are employed by Sanofi Pasteur, France. The other authors have no conflicts of interest to declare.

\section{References}

1. Martin M, Zingg W, Knoll E, Wilson C, Dettenkofer M, Group PS (2014) National European guidelines for the prevention of Clostridium difficile infection: a systematic qualitative review. $\mathrm{J}$ Hosp Infect 87(4):212-219. https://doi.org/10.1016/j.jhin.2014.05. 002

2. Feuerstadt P, Das R, Brandt LJ (2014) The evolution of Urban $C$. difficile infection (CDI): CDI in 2009-2011 is less severe and has better outcomes than CDI in 2006-2008. Am J Gastroenterol 109: $1265-1276$

3. Kim J, Kang JO, Kim H, Seo MR, Choi TY, Pai H, Kuijper EJ, Sanders I, Fawley W (2013) Epidemiology of Clostridium difficile infections in a tertiary-care hospital in Korea. Clin Microbiol Infect 19(6):521-527

4. Muto CA, Blank MK, Marsh JW, Vergis EN, O’Leary MM, Shutt KA, Pasculle AW, Pokrywka M, Garcia JG, Posey K, Roberts TL, Potoski BA, Blank GE, Simmons RL, Veldkamp P, Harrison LH, Paterson DL (2007) Control of an outbreak of infection with the hypervirulent Clostridium difficile BI strain in a university hospital using a comprehensive "bundle" approach. Clin Infect Dis 45(10): 1266-1273. https://doi.org/10.1086/522654

5. Lo Vecchio A, Zacur GM (2011) Clostridium difficile infection: an update on epidemiology, risk factors, and therapeutic options. Curr Opin Gastroenterol 28(1):1-9

6. Bishara J, Peled N, Pitlik S, Samra Z (2008) Mortality of patients with antibiotic-associated diarrhoea: the impact of Clostridium difficile. J Hosp Infect 68(4):308-314. https://doi.org/10.1016/j. jhin.2008.01.033

7. Eckert C, Coignard B, Hebert M, Tarnaud C, Tessier C, Lemire A, Burghoffer B, Noel D, Barbut F, Group IC-RW (2013) Clinical and microbiological features of Clostridium difficile infections in France: the ICD-RAISIN 2009 national survey. Med Mal Infect 43(2):67-74. https://doi.org/10.1016/j.medmal.2013.01.004

8. Khanafer N, Oltra L, Hulin M, Dauwalder O, Vandenesch F, Vanhems P (2016) Clostridium difficile infection in a French university hospital: eight years of prospective surveillance study. Medicine 95(23):e3874. https://doi.org/10.1097/MD. 0000000000003874

9. Bidet P, Lalande V, Salauze B, Burghoffer B, Avesani V, Delmee M, Rossier A, Barbut F, Petit JC (2000) Comparison of PCRribotyping, arbitrarily primed PCR, and pulsed-field gel electrophoresis for typing Clostridium difficile. J Clin Microbiol 38(7):2484 2487

10. Muto CA, Pokrywka M, Shutt K, Mendelsohn AB, Nouri K, Posey K, Roberts T, Croyle K, Krystofiak S, Patel-Brown S, Pasculle AW, Paterson DL, Saul M, Harrison LH (2005) A large outbreak of Clostridium difficile-associated disease with an unexpected proportion of deaths and colectomies at a teaching hospital following increased fluoroquinolone use. Infect Control Hosp Epidemiol 26(3):273-280. https://doi.org/10.1086/502539

11. Pepin J, Valiquette L, Cossette B (2005) Mortality attributable to nosocomial Clostridium difficile-associated disease during an epidemic caused by a hypervirulent strain in Quebec. CMAJ 173(9): 1037-1042. https://doi.org/10.1503/cmaj.050978

12. Barbut F, Jones G, Eckert C (2011) Epidemiology and control of Clostridium difficile infections in healthcare settings: an update. Curr Opin Infect Dis 24(4):370-376. https://doi.org/10.1097/ QCO.0b013e32834748e5
13. Rodriguez-Pardo D, Almirante B, Bartolome RM, Pomar V, Mirelis B, Navarro F, Soriano A, Sorli L, Martinez-Montauti J, Molins MT, Lung M, Vila J, Pahissa A (2013) Epidemiology of Clostridium difficile infection and risk factors for unfavorable clinical outcomes: results of a hospital-based study in Barcelona, Spain. J Clin Microbiol 51(5):1465-1473

14. Mascart G, Delmee M, Van Broeck J, Cytryn E, Karmali R, Cherifi S (2013) Impact of ribotype 027 on Clostridium difficile infection in a geriatric department. Eur J Clin Microbiol Infect Dis:1435-4373

15. Bartlett JG (2006) Narrative review: the new epidemic of Clostridium difficile-associated enteric disease. Ann Intern Med 145(10):758-764

16. Gould CV, Edwards JR, Cohen J, Bamberg WM, Clark LA, Farley MM, Johnston H, Nadle J, Winston L, Gerding DN, McDonald LC, Lessa FC, Clostridium difficile Infection Surveillance Investigators, Centers for Disease Control and Prevention (2013) Effect of nucleic acid amplification testing on population-based incidence rates of Clostridium difficile infection. Clin Infect Dis 57 (9):1304-1307. https://doi.org/10.1093/cid/cit492

17. Abou Chakra CN, McGeer A, Labbe AC, Simor AE, Gold WL, Muller MP, Powis J, Katz K, Garneau JR, Fortier LC, Pepin J, Cadarette SM, Valiquette L (2015) Factors associated with complications of Clostridium difficile infection in a multicenter prospective cohort. Clin Infect Dis 61(12):1781-1788. https://doi.org/10. 1093/cid/civ749

18. Henrich TJ, Krakower D, Bitton A, Yokoe DS (2009) Clinical risk factors for severe Clostridium difficile-associated disease. Emerg Infect Dis 15(3):415-422. https://doi.org/10.3201/eid1503.080312

19. Morrison RH, Hall NS, Said M, Rice T, Groff H, Brodine SK, Slymen D, Lederman ER (2011) Risk factors associated with complications and mortality in patients with Clostridium difficile infection. Clin Infect Dis 53(12):1173-1178. https://doi.org/10.1093/cid/ cir668

20. Tan ET, Robertson CA, Brynildsen S, Bresnitz E, Tan C, McDonald C (2007) Clostridium difficile-associated disease in New Jersey hospitals, 2000-2004. Emerg Infect Dis 13(3):498-500. https:// doi.org/10.3201/eid1303.060294

21. Evans CT, Safdar N (2015) Current trends in the epidemiology and outcomes of Clostridium difficile infection. Clin Infect Dis 60(Suppl 2):S66-S71. https://doi.org/10.1093/cid/civ140

22. Wiegand PN, Nathwani D, Wilcox MH, Stephens J, Shelbaya A, Haider S (2012) Clinical and economic burden of Clostridium difficile infection in Europe: a systematic review of healthcarefacility-acquired infection. J Hosp Infect 81(1):1-14. https://doi. org/10.1016/j.jhin.2012.02.004

23. Hall JF, Berger D (2008) Outcome of colectomy for Clostridium difficile colitis: a plea for early surgical management. Am J Surg 196(3):384-388. https://doi.org/10.1016/j.amjsurg.2007.11.017

24. Kasper AM, Nyazee HA, Yokoe DS, Mayer J, Mangino JE, Khan YM, Hota B, Fraser VJ, Dubberke ER, Centers for Disease C, Prevention Epicenters P (2012) A multicenter study of Clostridium difficile infection-related colectomy, 2000-2006. Infect Control Hosp Epidemiol 33(5):470-476. https://doi.org/10. 1086/665318

25. Barbut F, Gariazzo B, Bonne L, Lalande V, Burghoffer B, Luiuz R, Petit JC (2007) Clinical features of Clostridium difficile-associated infections and molecular characterization of strains: results of a retrospective study, 2000-2004. Infect Control Hosp Epidemiol 28(2):131-139. https://doi.org/10.1086/511794

26. Fenner L, Frei R, Gregory M, Dangel M, Stranden A, Widmer AF (2008) Epidemiology of Clostridium difficile-associated disease at University Hospital Basel including molecular characterisation of the isolates 2006-2007. Eur J Clin Microbiol Infect Dis 27(12): 1201-1207. https://doi.org/10.1007/s10096-008-0564-9

27. Pepin J, Alary ME, Valiquette L, Raiche E, Ruel J, Fulop K, Godin D, Bourassa C (2005) Increasing risk of relapse after treatment of 
Clostridium difficile colitis in Quebec, Canada. Clin Infect Dis 40(11):1591-1597. https://doi.org/10.1086/430315

28. Sim JH, Truong C, Minot SS, Greenfield N, Budvytiene I, Lohith A, Anikst V, Pourmand N, Banaei N (2017) Determining the cause of recurrent Clostridium difficile infection using whole genome sequencing. Diagn Microbiol Infect Dis 87(1):11-16. https://doi. org/10.1016/j.diagmicrobio.2016.09.023

29. Pepin J, Valiquette L, Alary ME, Villemure P, Pelletier A, Forget K, Pepin K, Chouinard D (2004) Clostridium difficile-associated diarrhea in a region of Quebec from 1991 to 2003: a changing pattern of disease severity. CMAJ 171(5):466-472. https://doi.org/10.1503/ cmaj. 1041104

30. Zilberberg MD, Shorr AF, Kollef MH (2008) Increase in adult Clostridium difficile-related hospitalizations and case-fatality rate, United States, 2000-2005. Emerg Infect Dis 14(6):929-931. https://doi.org/10.3201/eid1406.071447

31. Salazar M, Baskin L, Garey KW, DuPont HL (2009) Clostridium difficile-related death rates in Texas 1999-2005. J Inf Secur 59(5): 303-307. https://doi.org/10.1016/j.jinf.2009.08.019

32. Hensgens MP, Goorhuis A, van Kinschot CM, Crobach MJ, Harmanus C, Kuijper EJ (2011) Clostridium difficile infection in an endemic setting in the Netherlands. Eur J Clin Microbiol Infect Dis 30(4):587-593. https://doi.org/10.1007/s10096-010-1127-4

33. Abou Chakra CN, Pepin J, Sirard S, Valiquette L (2014) Risk factors for recurrence, complications and mortality in Clostridium difficile infection: a systematic review. PLoS One 9(6):e98400. https://doi.org/10.1371/journal.pone.0098400

34. Laza R, Jurac R, Crisan A, Lazureanu V, Licker M, Popovici ED, Baditoiu LM (2015) Clostridium difficile in western Romania: unfavourable outcome predictors in a hospital for infectious diseases. BMC Infect Dis 15:141. https://doi.org/10.1186/s12879015-0895-y

35. Karas JA, Enoch DA, Aliyu SH (2010) A review of mortality due to Clostridium difficile infection. J Infect 61(1):1-8. https://doi.org/10. 1016/j.jinf.2010.03.025

36. Davies KA, Ashwin H, Longshaw CM, Burns DA, Davis GL, Wilcox MH; EUCLID study group (2016) Diversity of Clostridium difficile PCR ribotypes in Europe: results from the European, multicentre, prospective, biannual, point-prevalence study of Clostridium difficile infection in hospitalised patients with diarrhoea (EUCLID), 2012 and 2013. Euro Surveill: 21 (29)

37. Wilcox MH, Shetty N, Fawley WN, Shemko M, Coen P, Birtles A, Cairns M, Curran MD, Dodgson KJ, Green SM, Hardy KJ, Hawkey PM, Magee JG, Sails AD, Wren MW (2012) Changing epidemiology of Clostridium difficile infection following the introduction of a national ribotyping-based surveillance scheme in England. Clin Infect Dis 55(8):1056-1063. https://doi.org/10. 1093/cid/cis614

38. Warny M, Pepin J, Fang A, Killgore G, Thompson A, Brazier J, Frost E, McDonald LC (2005) Toxin production by an emerging strain of Clostridium difficile associated with outbreaks of severe disease in North America and Europe. Lancet 9491:1079-1084. https://doi.org/10.1016/S0140-6736(05)67420-X

39. Walk ST, Micic D, Jain R, Lo ES, Trivedi I, Liu EW, Almassalha LM, Ewing SA, Ring C, Galecki AT, Rogers MA, Washer L, Newton DW, Malani PN, Young VB, Aronoff DM (2012) Clostridium difficile ribotype does not predict severe infection. Clin Infect Dis 55(12):1661-1668. https://doi.org/10.1093/cid/ cis786 